\title{
ENHANCING LEARNERS' REFLECTIONS IN THE PROCESS OF LEARNING ELF PRONUNCIATION THROUGH TECHNOLOGY-BASED SELF-STUDY
}

\author{
Enhancing learners' reflections in the process of learning EFL \\ pronunciation through technology-based self-study
}

This article reports the findings of a qualitative study aimed at investigating how the use of technology-based resources in out-of-class selfstudy by learners of English affects their level of reflectivity during the process of learning pronunciation. Using as a research tool learners' diaries submitted on Moodle, the study also explores the value of such diaries in promoting reflection in learners. The findings largely confirmed the considerable role played by technology-based self-study and diary writing in enhancing reflection on learning pronunciation in the participants. These reflections concerned their growing phonological awareness, the use of materials appropriate for pronunciation practice, pronunciation learning strategies, and the affective side of learning. The didactic implications include the need to employ a wide range of technology-based resources for self-study and to encourage learners to keep reflective diaries as part of their pronunciation instruction.

Keywords: reflection, pronunciation, self-study, technology-based resources, learning diary

Słowa kluczowe: refleksja, wymowa, samodzielne uczenie się, technologia, dziennik uczenia się 


\section{Introduction}

The contemporary focus on learner-centeredness in foreign language education highlights the role of active learner involvement in the teaching process and stresses the role of learner reflection in effective learning. Reflection is considered to enrich the learning experience by encouraging learners' to think about what, why and how they learn, engaging their emotions, and highlighting the positive actions resulting from learning (Hinett, 2002; Ghaye, 2011). It helps learners acquire new insights from the material they study, apply new knowledge to their own experience, and learn more about their own learning processes. This, in turn, leads to "deep learning" (Moon, 2004) and lays the foundations for their taking more effective actions in the future. Learner reflectivity may be promoted in various ways, of which using technology-based resources and keeping a diary are often cited (Vitanova and Miller, 2002; Strampel and Oliver, 2007).

As suggested by researchers (e.g. Setter and Jenkins, 2005; Levis, 2007; Chun, 2012; Zhang, 2012), technology-based resources for learning pronunciation offer numerous benefits to learners, one of which is providing easy access to relevant $L 2$ input. This considerably increases learners' exposure to natural, native-like speech (Derwing, 2008), which may contribute to raising learners' phonological awareness. Furthermore, self-study with technology allows learners to gain independence from teachers, providing them with opportunities to try out various pronunciation learning strategies and enhancing their motivation to learn pronunciation (Strampel and Oliver, 2007).These factors may also stimulate learners to reflect on their practice and progress.

This article describes the outcomes of a study which investigated the role of pronunciation learning undertaken by learners out of class through using Internet-based media as ways of promoting reflection about pronunciation learning processes. First, however, the concepts of reflection in learning L2 in general, and in learning L2 pronunciation with the use of technology in particular, are discussed.

\section{The role of reflection in learning a foreign language}

According to most definitions (e.g. Hinett, 2002), reflection encompasses thinking about learning and trying to understand what and why we learn. Reflective "mental processing" (Moon, 2004: 82) also has an affective dimension, as it embraces feelings and emotions associated with the newly learned knowledge, the material to be learned, one's learning processes, and the learning situation. 
If reflection becomes a part of learning, it usually leads to further processing of ideas and, eventually, to an improvement in learning. As noted by Moon (2004: 82), reflection that is triggered by thinking about complex ideas often brings about specific outcomes, whether anticipated or unexpected, which help us shape our future actions by looking back at what has happened and linking this with present or future activity. The importance of reflecting on problem-oriented activity is stressed by Ghaye (2011), for whom reflection helps learners develop new insights into problems and find new ways of understanding them. Therefore, he sees reflection as "skilled practice that uses experience, knowledge and inquiry processes to increase our capability to intervene, interpret, and act positively on successes, problems, issues, and significant questions" (Ghaye, 2011: 20).

Ghaye (2011) concludes that reflection fosters the following kinds of learning: affective learning (by controlling feelings and emotions in the process of learning), cognitive learning (by developing different, and perhaps more creative ways of thinking), positive action learning (by turning thinking into action), and social learning (by learning with and from others). Highlighting the relationship between reflection and action, Moon (1999) notes that reflection is involved in experiential learning, which consists in constructing one's learning in a practical situation. In other words, this kind of learning allows learners to make sense of experience. Hinett (2002) states that reflection leads a learner from experience to understanding. Elements of reflective activity in experiential learning include, among others, noticing the need to tackle a problem, clarifying relevant issues, reviewing one's emotions, mentally processing knowledge and ideas, and, possibly, taking action that leads to improvement (Moon, 1999; 2004).

Summing up these ideas, Moon (2004: 86) states that reflection takes learners from "surface" to "deep" learning, which involves an orientation to meaning and a readiness to modify one's "cognitive structure". In meaningful, reflection-based learning, material is reviewed and reconsidered from a new perspective or from one based on new experience. Therefore, it can be concluded that reflection creates favorable learning conditions by regulating the pace of learning and developing a "sense of ownership of learning" in the learner, thus making this experience more personal. Another point worth mentioning here is that reflection can stimulate metacognition; through reflection, learners discover more about their learning processes and strategies, and through critical self-evaluation embedded in reflection they recognize their own strengths and weaknesses as learners. Therefore, Moon makes the point that reflection is an element of "good quality learning", contributing to the development of "appropriate learning behavior". 
Such learning is based on constructivist principles, as it challenges the learner, involves a restructuring of cognitive structures, and leads to active creation of meaning representations. Similarly, Dantas-Whitney (2002) sees the link between reflectivity and constructivist learning in that reflection leads the learner to the ability to construct their own ideas on the basis of existing knowledge. As Race (2002) puts it, reflection helps a learner internalize and personalize newly acquired knowledge.

As can be concluded from the discussion above, reflection is an ability that should be fostered in learners, at least in those who are mature enough to benefit from it in their learning processes. Kohonen (2007) lists several ways in which reflection can be developed, for example: writing diaries and reflective personal essays, keeping a portfolio, participating in drama activities, telling personal stories, investigating case studies, and taking part in reflective discussions in cooperative groups. In addition, technology-based materials, which are particularly suitable for self-study, as they are both authentic and stimulating, may also be useful in promoting reflective learning (Henett, 2002; Strampel and Oliver, 2007).

\section{The role of technology in fostering reflection in L2 pronunciation learning}

The contemporary communicative paradigm in language learning and teaching offers numerous possibilities for designing pronunciation practice activities which are adjusted to learners' needs. These pedagogical options range from "surface" to "deep" learning activities, to use Moon's terminology (2004), described in the previous section. "Surface" activities are based on mechanical practice, such as repetition, imitation, or sound discrimination, and stimulate little reflectivity in learners. "Deep" activities, preferred mostly by more mature learners, can involve cognitive analysis and strategy training (Pennington, 1995; Seidlhofer, 2001; Jones, 2002), and are more likely to promote reflection on learning processes. Reflection is likely to be stimulated in $\mathrm{L} 2$ pronunciation instruction when conditions are provided for performing authentic tasks, for becoming involved in interaction with one's peers and other L2 users, and for receiving naturalistic feedback, all of which help learners to become critical listeners, improve their ability to notice and correct their own errors, and discover their own preferred ways of learning (Zhang, 2012).

Since a teacher's control over most of the factors that influence learners' development of pronunciation (such as age, L1, aptitude, etc.) is limited (Jones, 2002; Derwing, 2008; Wrembel, 2008; Pawlak, 2011), there is an urgent need to raise learners' awareness of the role of pronunciation in their 
overall language development. Therefore, training learners in the use of effective pronunciation learning strategies and encouraging self-study are of the utmost importance. Out of the countless resources that learners can exploit in learning pronunciation, technology-based materials are particularly worth mentioning, because, as stated by Levis (2007: 184) in a discussion of the merits of computer-assisted pronunciation teaching (CAPT), "[c]omputers can provide individualized instruction, frequent practice through listening, discrimination and focused repetition exercises, and automatic visual support that demonstrates to learners how closely their own pronunciation approximates model utterances".

Learners' access to naturalistic Internet-based input is the main focus of this article and of the study presented in the following section, rather than the numerous software applications typically discussed within computer-assisted language learning (CALL) (for reviews of such applications, see, for example, Levis, 2007; Chun, 2012). For this reason, only a selection of CALL applications, particularly those most suitable for self-instruction, will be mentioned here. Speech synthesis and automatic speech recognition (ASR) are the most common pronunciation training applications provided by technology. Speech synthesis programs are used for recognizing soundsymbol correspondences, and are useful in improving listening comprehension and sound production (Chun, 2006; Busa, 2008). ASR tools, which provide both audio and visual feedback, enable learners to compare their own pronunciation to sounds produced by native speakers, detect and correct their own mistakes, and thus are particularly appropriate for self-study in learning pronunciation (Chun, 2006; Ducate and Lomicka, 2009; Zhang, 2012). Podcasts are another tool typically used in pronunciation practice which offer numerous benefits to learners; they present pronunciation features in a contextualized way, and have been found to improve learners' pronunciation abilities and their attitudes toward pronunciation practice (Lord, 2008; Ducate and Lomicka, 2009). Sobkowiak (2012) discusses the great potential of the Second Life (SL) virtual environment in learning pronunciation. The author presents a series of activities with the use of Phonetically Augmented Virtual objects, such as sound files, test items, and transcriptions, set up within the virtual reality of SL. Immersion in the foreign language context, easy transfer to other learning conditions, and collaboration among users are the main advantages of the use of SL-based techniques in pronunciation training.

Technology creates numerous opportunities for learner self-study, including possibilities of increased exposure to spoken English. This seems to be a particularly relevant point, since the degree of exposure to $L 2$ is an important factor in learning pronunciation, and in settings where English is a 
foreign language, technology can, to a large extent, compensate for a lack of exposure to spoken L2 through naturalistic interactions. As stated by Derwing (2008: 357), "[i]n EFL and some EIL settings, media such as radio, television, movies, books on tape and the Internet may all provide a range of voices, dialects, and accents to augment classroom-based input".

Although providing rich exposure to $L 2$ is a great advantage of technology-based resources for learning pronunciation, it is not the only one. Apart from this, as noted by Setter and Jenkins (2005) and Strampel and Oliver (2007), the use of technology may change the traditional roles of learners and teachers, making learners more independent and active. It also provides access to good quality, relevant input, whose appeal additionally lies in the fact that it is often selected by the learners themselves; hence, this input may be perceived as more attractive and motivating for learners. Moreover, technology provides a "safe space" for learners to study pronunciation, without supervision from the instructor, while the flexibility and portability offered by technological devices contribute to the practicality of using technology-based input.

Pawlak (2011: 169-170) lists a number of factors which affect success in pronunciation learning, and which can be controlled, at least to a certain degree, by teachers and learners. It seems that these factors are also likely to foster reflective thinking within the context of learning pronunciation. These factors include enhancing the motivation to master foreign language sounds, getting enough in- and out-of-class exposure to spoken L2, raising learners' awareness of pronunciation issues, selecting and applying appropriate learning strategies, and fostering learner autonomy. Technologybased resources thus seem to be a promising option for enhancing learner reflectivity, and, possibly, the effectiveness of how they learn pronunciation.

\section{The aims of the study}

The present study was based on action research, and its primary aim was to stimulate students' reflectivity during the process of learning the pronunciation of English as a foreign language. More specifically, this involved increasing learners' phonological awareness, encouraging them to use various metacognitive and cognitive strategies, to monitor the affective factors that accompanied pronunciation learning, and to discover which strategies worked best for them. Apart from these primarily educational aims, another objective was to evaluate the effectiveness of technology-based resources and the technique of keeping a diary as tools for enhancing reflection. 


\section{The design of the study}

The participants of the study were 16 first-year students majoring in both Russian and English in a three-year BA program. Their level of English was roughly at the B2/C1 level. Once a week, the group attended a practical American English pronunciation course and a theory-oriented phonetics course in which they became acquainted with the phonological system of English. The study lasted for the 15 weeks of the summer term, and the main focus of instruction during this time, according to the course syllabus, was on practicing the consonants $/ \theta /, / \delta /$ and $/ \mathrm{y} /$, and all vowels. At the end of the academic year the students took an exam in spoken English, in which pronunciation was one of the components being assessed; therefore, it could be assumed that they were highly motivated to learn correct pronunciation.

The main teaching material used in the practical pronunciation classes was Say It Right (Sawala et al., 2012), a multimedia interactive English pronunciation course, which contains a number of recorded repetition drills, texts and many other tools for practicing either British or American English pronunciation, both in class and outside it. Apart from using this resource, students were assigned to listen to the American English Pronunciation Podcast (by Seattle Learning Academy) on a regular weekly basis; each week they were supposed to listen to one or two specifically assigned podcasts connected with the sounds that were practiced in class. They were also encouraged to listen to authentic materials in their own time as often as possible to ensure intensive exposure to American English pronunciation.

The students were also required to make weekly entries in diaries devoted to their pronunciation learning practice on the Moodle platform; the diaries they submitted became the data collection tool in the present study. According to Pavlenko (2007: 164-165), the power of autobiographical narratives, of which learner diary is an example, is that they "offer insights into people's private worlds" and "highlight new connections between various learning processes and phenomena", and thus were considered to be an appropriate research tool in this study. The language of the participants' diaries was English. At the beginning of the study, that is, during the first class of the summer term, the students received training in writing language learning diaries (as none of them had ever kept a learning diary before), during which sample pronunciation learning diary entries (taken from Vitanova and Miller, 2002) were presented together with the following instruction which contained a list of prompts that they were encouraged to refer to when writing their diaries:

In your diaries, please include the following points, to make them personal accounts of your pronunciation learning processes: 
- Your specific ways of learning: what texts you listen to, what exercises you do, how you practice pronunciation outside class;

- What helps you learn pronunciation as well as the problems that you encounter;

- What you find easy and what you find difficult;

- What you like and what you dislike;

- Why you learn pronunciation, how important good pronunciation is for you;

- How confident you feel as a learner;

- Your frustrations, sources of stress and anxiety;

- Your successes and achievements, etc.

\section{Data collection and analysis}

Altogether, 128 diary entries were collected during the course of the study, and they constituted the research data in the present study. The entries varied considerably both in terms of length and the depth of reflection they expressed. While some were merely brief and dry accounts of what a student did to practice pronunciation during a given week, others were in-depth, vivid descriptions of learning procedures, thoughts, doubts and beliefs, often written with high levels of personal involvement and a sense of humor. Needless to say, the latter generated the bulk of the research data and will comprise a substantial part of the material referred to in this section. The diary entries yielded qualitative data, which were analyzed and coded according to the most frequent themes concerning the participants' pronunciation learning. The analysis of the data thus followed the basic principles of grounded theory (Dörnyei 2007), as they were coded to establish the frequency of particular pronunciation-learning themes and to detect the most commonly recurring ones. On the basis of this initial analysis, the following themes emerged: students' phonological awareness, the materials they used, ways of practicing pronunciation features, and affective factors involved in pronunciation learning. The findings will be presented under these headings.

\section{The findings of the study}

\section{Phonological awareness}

A number of the diary entries illustrate the students' reflections about their emerging awareness of the phonological system of English. This is evident in the following quotations from the students' diaries: "I find it very difficult to 
produce the 'th' sounds. Firstly, I am not sure about what they really should sound like. Sometimes they seem to me to sound more like /v/ and /f/, sometimes the voiced one sounds to me exactly like the /d/ sound"; "I also tried to focus on my mistakes in producing "th" sounds and in my opinion, I've improved these sounds but I am still not as confident about them as I should be. However, I think I have some problems with / / and /a/".

Some notes expressed reflections concerning work during classes, as in the following example, which concerns a comparison of selected English and Polish sounds: "During our last lesson of descriptive grammar of English we compared the Polish sounds and the English ones. I have to admit that I was quite surprised with how many differences there are between them. Even such sounds like /t/ or / // differ in both languages and now I know that producing almost all of the English sounds requires a lot of practice".

The following quotations reveal motivation to learn more about the phonological system of English as a result of exposure to authentic input: "I have noticed that I pay more attention to pronunciation of the actors and singers. I could say that I became more aware of English and it is quite funny (or strange...) to watch a movie and think or say 'Oh look, it was the "schwa" sound! Did you hear it? I love the way she's pronouncing the "ash" sound!' I hope this is helpful in learning English pronunciation, because some people get a little annoyed watching movies with me..."; "From the research I've done after hearing characters [of a tv series] saying [ja:l], [ænd] and [git] all the time, it turned out that they come mostly from Georgia (GA) and, indeed, sound southern"; "Listening to Arctic Monkeys frontman's Yorkshire accent combined with Southern US accent and a little bit of Californian hiphop can set me out of tune:-)".

Some of the entries illustrated the doubts that the students had about pronunciation patterns: "Watching a movie, I was confused when one of the actors pronounced some words in a different way than we are learning. He is American, so maybe his dialect is characteristic to the place where he came from". Similarly, other diary entries highlighted the challenges of matching newly acquired knowledge with adequate perception, as well as with producing sounds in English, as illustrated by the following two quotes: "Yesterday I started reading 'Forrest Gump' in original and I felt strange sometimes because there were plenty of words that I wasn't able to pronounce and I tried to guess if there is a schwa, wedge or another sound"; "I've been practicing one vowel lately - it's called 'wedge'. I'm not really fond of this one, I guess... It's getting on my nerves because it's not 'obvious'. I don't like things that are not obvious! I admit that in the word 'come' it's visible (hearable, I would say), 
but let's take 'does' into consideration. No, I don't think so... But if Americans say so, I cannot disagree. I just have to repeat it once again".

\section{Materials used}

As stated before, apart from using the course materials from Say It Right and listening to podcasts on American English pronunciation as obligatory homework practice at least once a week, the students were strongly encouraged to get abundant exposure to natural authentic input in their free time. A large number of the diary entries show that the students deliberately looked for and listened to different kinds of texts in English in their own time. As the following examples show, television series (watched online or downloaded from the Internet) and songs were the favorite kinds of input: "Except for [sic] practicing 'th' for the recording (material from 'Say It Right', which wasn't as easy as I thought) and listening to the podcasts, I watched a lot this week: 3 or 4 episodes of 'The Walking Dead', a movie titled 'Zombie Strippers' (maybe not a very ambitious one, but still better than nothing and I like this kind of movies) with no subtitles turned on"; "Moreover, I watched a couple of English TV series - 'The big bang theory' and 'Pretty little liars'. Listening to actors who fluently speak American English helps me to remember some word formations as well as to practice correct pronunciation"; “In my free time I watched an episode of Conan O'Brien's web show 'Serious Jibber-Jabber' featuring Jack, White-American musician of Detroit origin with a clear midwestern accent who seems to be an excellent role model in this matter"; "Besides, every day I listen to American songs. My favorite bands are 'Guns and Roses' and 'The Killers'”.

Apart from television series, movies and songs, some of the students mentioned making use of websites designed specifically to practice spoken English (e.g. talkenglish.com) or other materials from the Internet, such as TED talks, which were also exploited in classes. One student wrote: "I found other speeches, for example Bill Gates' or Steve Jobs' and I have to say that it is very inspiring to hear their ideas or feelings. Since that time I try to listen one or two speeches three times in week from Ted Talks". Audiobooks were also mentioned by the students as being useful for pronunciation practice: "Today I was listening to the audiobook 'A short story about nearly everything' by Bill Bryson. It took me quite long time, but I think the audiobook is worth listening to. Not only because of its interesting contents, but also the nice American accent of the reader"; "Whenever I can, on the tram, or walking in the street, I listen to audiobooks. In this way, I get a lot of exposure to American English pronunciation". 
Electronic dictionaries were another learning aid referred to by the students in their diaries, as in this entry: "This week I've also decided to install the digital version of Professor Wells's Longman pronunciation dictionary on my computer and as it turns out, I should have done it long ago. It seems like just as 'Say it Right', it will be one of my basic tools for the purpose of improving my pronunciation".

Seeking contacts with native speakers and engaging in conversations with them, either in face-to-face or online interactions, was another source of input considered by the students as valuable for their pronunciation practice: "During Juwenalia festival I met a peer from America. I'm really glad about this not only because he keeps an eye (or an ear!) on my grammar and pronunciation, but he is also a cool guy"; "On the Language Exchange website I started a conversation with an American guy! He is from Chicago, so obviously he is eager to learn some Polish because he is surrounded by Poles. Finally, I have someone that I could practice my American accent with! The only problem is time change so unfortunately we don't have many opportunities to talk".

Finally, obligatory course materials were also frequently quoted by the students as valuable aids in learning pronunciation, which can be seen in these diary excerpts: "What is more, I listened to the $1^{\text {st }}$ and the $2^{\text {nd }}$ podcasts. I must admit that they are really interesting. The sentence 'Think about this thing, that thing and those things' was quite a challenge at the beginning, but now, I believe, I can pronounce it correctly"; "As usual, the 'Say It Right' multimedia course turned out to be helpful, clearly pointing out aspects that need to be worked on. Still a long way to go!"

\section{Ways of practicing}

The materials employed by the students were exploited by them in different ways, some of which could be considered traditional strategies for working on pronunciation, such as repeating after the tape. These strategies were often applied in conjunction with the Say It Right course, which contains numerous repetition drills and was also used in this way in class. Transcribing words and repetition were the most frequently mentioned strategies, as illustrated by the following quote: "I wrote down all words with "nga" from the exercises and texts and transcribed them. Later on I practiced them, reading aloud single words first, then whole sentences. I hope it will be ok!"

The repetition strategy was also transferred to working with other kinds of materials, such as songs: "I did some exercises from Say it Right and, as usual, I listened to a lot of songs in English and tried to repeat after the singer". The value of background music as a way of providing input for less conscious pronunciation practice was also mentioned: "As always, I listen to 
American music for most of the time, even when studying. I guess that it's one of the most effective ways of familiarizing oneself with American sounds, even when those sounds are only being played in the background without us really consciously noticing them".

Referring to the transcription of words in a dictionary (usually, an electronic one) was also noted as a frequent and useful strategy. The following examples show that looking up the pronunciation pattern of words often accompanied other activities, such as reading or learning vocabulary: "Recently, when reading books in English, I check the meaning of new words and I always check their pronunciation in the online Longman dictionary"; "Having a pronunciation dictionary constantly turned on my pc is noteworthy [sic], as it has become my habit to look up new words in it when learning vocabulary or even when not studying".

Some entries reveal the learners' doubts concerning the usefulness of the strategies they used, as illustrated by these quotes: "I also talked to my roommate in English. I don't know actually if I talked to her in a correct way because I tried to do it automatically, without focusing on pronunciation. I tried to feel as if I lived in the USA. So maybe it's not so good for practicing pronunciation"; "This week I've watched a series in English, and a movie in English but with subtitles, so I'm not sure if it counts as practicing pronunciation".

\section{Affective factors}

The students' affective reactions to learning pronunciation were the most frequent thematic strand in the pool of diary entries in the study. The students often wrote about what gave them pleasure in learning pronunciation: "I like practicing through listening to music because while I am doing this, I'm putting together something I like with something useful"; "I also watched the film ' 500 Days of Love', and I'm pretty much convinced that I understood everything the actors were saying. I think that it's a good way of improving your pronunciation: you're resting and learning by doing one thing! [sic]".

The students also wrote about what gave them satisfaction: "I've found a moment during the weekend to watch a new movie, 'The Place Behind the Pines'. It felt really good when I needed no subtitles to understand the dialogs"; "Last Wednesday I met an American guy from Florida. I talked with him for quite a long time, and I had no problems with understanding him. This made me really happy, because I consider understanding natural, casual speech as one of the most important elements of language practice".

Negative feelings were also expressed. These quotes illustrate some of the students' concerns: "I listened to my weekly portion of podcasts, which I frankly find boring, but probably a valuable source of knowledge"; "I've 
watched some TED conference lately. But it was science stuff, not really interesting for me. Maybe I should find something about cooking next time"; "This week I've been studying the "th" sounds. Frankly speaking those two are the ones of the toughest to master if not the toughest, especially when it comes to fast speech, and practicing them is really hard work"; "Today I was listening to a British radio program. There were guests from USA, so I was paying attention to their pronunciation. Sadly, I realized that I will probably never speak like them!" One student expressed her negative feeling associated with speaking to her colleagues in English: "Today I have been conversing in English with my friends. I still have a problem with talking in front of a group. I'm always getting stressed and have emptiness in my head then. I do hate it!" However, despite the deficiencies they noticed in their pronunciation, most of the students felt optimistic about the future prospects of their language performance as a result of practice: "Of course, my "th" is still not perfect, but I will make efforts to improve it. I hope that soon I will pronounce it clearly"; "I can't wait till no one recognizes that I'm an East-European girl ;)".

\section{Discussion}

The diaries encouraged the participants to reflect on numerous areas of their pronunciation learning experience. They developed, or at least, had a chance to demonstrate, the skill of relating knowledge gained in classes with what they learned during their personal, and often highly informal, learning situations out of class.

During self-study, which in most instances was based on technologybased materials, the learners critically re-evaluated their explicit knowledge of the English phonological system as well as the usefulness of certain kinds of input and ways of exploiting them for pronunciation practice. The new knowledge about the phonological system of English that they gained in their classes, together with the experience of listening to authentic nativespeaker L2 performance through the Internet-based media, can be said to have stimulated a high degree of reflection in the participants, as was visible in their diaries. It is clear from the data that the students approached the sounds they were practicing with high levels of awareness. They reflected upon their perceptions of different sounds, and on the varieties of English they heard, as well as on differences between Polish and English sounds. A few of the students voiced interest in native speakers' accents and a willingness to learn more about them. This interest was apparently stimulated by the explicit knowledge that the students had gained in the process of learn- 
ing pronunciation. It can be concluded that technology-based resources turned out to be valuable sources of exposure to relevant, authentic input, which generated the learners' interest, stimulated reflection about the phonological system of English, and motivated them to explore it further.

Throughout the diaries some students expressed consistent doubts evoked in a simultaneous processing of meaningful authentic input and explicitly concentrating on its phonological features. These doubts may be generating reflections on the possible causes of differences in pronunciation patterns in some words, or, more generally, on variability in the pronunciation of sounds in authentic native-speaker speech. Doubts about the appropriate perception or production of sounds, so frequently expressed in the diary entries, may be interpreted as indicating reflective thinking. Reflective learning involves trying different ways to understand the material, or, as expressed by Hinett (2002), making "the new piece of the jigsaw 'fit' into the existing picture that we have", in spite of the doubts and uncertainties this evokes.

Many of the reflections stimulated by self-study were about the learners' trying out different pronunciation learning strategies. It was evident that when the students felt free to choose their own materials for selfstudy, they discovered new ways of learning. This was largely facilitated by Internet resources, such as songs, movies, television series and audiobooks, as these turned out to be the most appealing and motivating to the students. It seems important to note here that much of what the students did during self-study reflected strategies they were encouraged to use in class, especially when making use of authentic materials. They had a chance to experiment with and reflect on these strategies on their own. This is worth highlighting, because, as stated by many researchers (Wrembel, 2008; Pawlak, 2011), the recognition of learning strategies and their effective use are important factors influencing success in learning.

Finally, the study revealed the great importance of the affective side of learning pronunciation, a factor which is, according to Vitanova and Miller (2002), largely neglected in studies on L2 pronunciation learning and teaching. The self-evaluation comments expressed both positive and negative feelings associated with learning, as well as giving examples of ways of controlling these emotions. It is evident from the quotations that interest in the materials was the main factor that motivated the students and, not surprisingly, the main criterion they applied to select input for self-study. The ability to comprehend natural, native-speaker speech was considered by the students as evidence of progress, and was a source of positive selfevaluation which gave them a feeling of accomplishment. Comments highlighting these kinds of positive feelings were frequent in the diaries, and 
concerned both listening to Internet materials and contacts with native speakers. Negative emotions were triggered by a lack of involvement with some of the materials, the difficulty of the material they had to practice, and their frustration with sounding non-native.

\section{Final conclusions and implications}

The main conclusion that can be formulated on the basis of the research is that both self-study based on technology-mediated materials and the technique of writing diaries were found to stimulate student reflections on their pronunciation learning processes. The materials employed by the students for self-study stimulated reflections about different pronunciation patterns, similarities and differences between English and Polish sounds, the accuracy of the learners' own pronunciation, and the efficiency of the strategies they used. Although the obligatory class materials were evaluated by the students as useful, a deeper involvement was stimulated by authentic materials, such as movies, television series, and songs, selected by the students themselves.

The findings obtained in this study lead to a formulation of two didactic implications. The main implication stresses the role of technology-mediated materials for learners' self-study. Nowadays, when access to valuable, good quality input is relatively easy due to the advancements in technology, students need to be encouraged to look for appropriate materials, and trained in how to exploit them for self-study, as this may stimulate experiential learning in a motivating way. The other implication concerns the beneficial effects of the diary writing technique for fostering reflections in learners. Although reflective thinking is a challenge for learners, opportunities for its development must be created in order to facilitate improved learning and understanding.

\section{BIBLIOGRAFIA}

American English Pronunciation Podcast (by Seattle Learning Academy) (dostęp: https:// itunes.apple.com/us/podcast/american-english-pronunciation/id276921054, odczyt: 7.06.2013).

Busa, M. G. 2008. „New perspectives in teaching pronunciation” (dostęp: http://etabeta .univ.trieste.it/dspace/bitstream/10077/2850/1/bus\%C3\%A0.pdf, odczyt: 3.07.2013).

Chun, D. 2006. „Technological advances in researching and teaching phonology”. (w:) Pennington, M. C. (red.). Phonology in context. Luton: Palgrave Macmillan. 274-299.

Chun, D. 2012. "Computer-assisted pronunciation teaching”. (w:) Chapelle, C. (red.). The Encyclopedia of applied linguistics. Oxford: Wiley-Blackwell. 823-834. 
Dantas-Whitney, M. 2002. „Critical reflection in the second language classroom through audiotaped journals". (w:) System 30: 543-555.

Derwing, T. 2008. „Curriculum issues in teaching pronunciation to second language learners". (w:) Hansen Edwards, J. I. i Zampini, M. (red.) Phonology and second language acquisition. Amsterdam/Philadelphia: John Benjamins Publishing Company. 347-369.

Dörnyei, Z. 2007. Research methods in applied linguistics: quantitative, qualitative, and mixed methodologies. Oxford: Oxford University Press.

Ducate, L. i Lomicka, L. 2009. „Podcasting: An effective tool for honing language students' pronunciation?”. (w:) Language Learning \& Technology 13: 66-86.

Ghaye, T. 2011. Teaching and learning through reflective practice. A practical guide for positive action (2nd edition). London and New York: Routledge.

Hinett, K. 2002. Improving learning through reflection - part one. The Higher Education Academy. (dostęp: http://heacademy.ac.uk/assets/documents/resources/data base/id485_improving_learning_part_one.pdf. odczyt: 3.07.2013).

Jones, R. 2002. „Beyond “Listen and Repeat”: Pronunciation teaching materials and theories of second language acquisition". (w:) Richards, J. i Renandya, W. (red.). Methodology in language teaching. An anthology of current practice. Cambridge: Cambridge University Press. 178-187.

Kohonen V. 2007. „Learning to learn through reflection - an experiential learning perspective". (w:) Preparing teachers to use the European language portfolio - arguments, materials and resources. New York: Council of Europe Publishing (dostęp: http://archive.ecml.at/mtp2/Elp_tt/Results/DM_layout/00_10/05/ Supplementary\%20text\%20E.pdf, odczyt: 20.08.2013).

Levis, J. 2007. „Computer technology in teaching and researching pronunciation”. (w:) Annual Review of Applied Linguistics 27: 184-202.

Lord, G. 2008. „Podcasting communities and second language pronunciation”. (w:) Foreign Language Annals 41: 364-379.

Moon, J. 1999. Reflection in Learning and Professional Development, Theory and Practice. London: Kogan Page.

Moon, J. 2004. A handbook of reflective and experiential learning: theory and practice. New York: Routledge Falmer.

Pavlenko, A. 2007. „Autobiographic narratives as data in applied linguistics”. (w:) Applied Linguistics 28: 163-188.

Pawlak, M. 2011. „Students' successes and failures in learning foreign language pronunciation: Insights from diary data". (w:) Arabski, J. i Wojtaszek, A. (red.). The Acquisition of L2 Phonology. Bristol: Multilingual Matters. 165-182.

Pennington, M. 1995. „Recent research in second language phonology: Implications for practice". (w:) Morley, J. (red.). Pronunciation, pedagogy and theory: New views, new directions. Alexandria, VA: TESOL. 94-108.

Race, P. 2002. „Evidencing reflection: putting the ' $w$ ' into reflection”. (dostęp: http:// escalate.ac.uk/resources/reflection/, odczyt: 12.08.2013). 
Sawala, K., Szczegóła, T., Jankowski, M. i Weckwerth, J. 2012. Say it right - multimedialny kurs wymowy $i$ słownictwa angielskiego wersja 3.0. poprawiona (+ DVD-ROM). Poznań: SuperMemo World - Oficyna Wydawnicza Atena.

Seidlhofer, B. 2001. „Pronunciation”. (w:) Carter, R. i Nunan, D. (red.). The Cambridge guide to teaching English to speakers of other languages. Cambridge: Cambridge University Press. 55-65.

Setter, J. i Jenkins, J. 2005. „Pronunciation”. (w:) Language Teaching 38: 1-17.

Sobkowiak W. 2012. Five years in second life, or: phonetically augmented virtuality in second life english as a foreign language. On-line: Scribd. (dostęp: http:// www.scribd.com/doc/108718699/Paving-EFL-in-SL, odczyt: 6.02.2013).

Strampel, K. i Oliver, R. 2007. „Using technology to foster reflection in higher education”. (w:) ICT: Providing choices for learners and learning. Proceedings Ascilite Singapore 2007. (dostęp: http://www.ascilite.org.au/conferences/singapore07/procs/ strampel.pdf, odczyt: 6.06.2013).

Vitanova, G. i Miller, A. 2002. „Reflective practice in pronunciation learning”. (w:) The Internet TESL Journal 8. (dostęp: http://iteslj.org/Articles/Vitanova-Pronunciation .html, odczyt: 6.06.2013).

Wrembel, M. 2008. „In search of effective strategies for L2 pronunciation teaching and learning". (w:) Pawlak, M. (red.). Investigating english language learning and teaching. Poznań-Kalisz: Adam Mickiewicz University Press. 179-194.

Zhang, F. 2012. „Combining the body and mobile technology to teach English pronunciation”. (w:) Zhang, F. (red.). Computer-enhanced and mobile-assisted language learning: emerging issues and trends. Hershey PA: IGI Global: 202-219. 